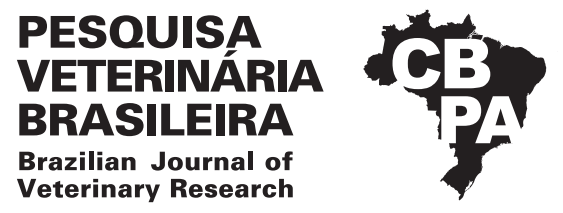

Pesq. Vet. Bras. 38(11):2023-2028, novembro 2018 DOI: 10.1590/1678-5150-PVB-5661

Original Article

Animais de Produção/Livestock Diseases

ISSN 0100-736X (Print)

ISSN 1678-5150 (Online)

\title{
Cattle trade between and within biomes in the state of Mato Grosso, Brazil ${ }^{1}$
}

\author{
Rísia L. Negreiros², José H.H. Grisi-Filho ${ }^{3}$, Ricardo A. Diass ${ }^{3}$, Fernando Ferreira ${ }^{3}$, \\ Valéria S.F. Homem ${ }^{4}$, José S. Ferreira Neto ${ }^{3}$, Raul Ossada ${ }^{3}$, and Marcos $\mathrm{Amaku}^{3 *}$
}

\begin{abstract}
Negreiros R.L., Grisi-Filho J.H.H., Dias R.A., Ferreira F., Homem V.S.F., Ferreira Neto J.S., Ossada R. \& Amaku M. 2018. Cattle trade between and within biomes in the state of Mato Grosso, Brazil. Pesquisa Veterinária Brasileira 38(11):2023-2028. Faculdade de Medicina Veterinária e Zootecnia, Universidade de São Paulo, Avenida Prof. Dr. Orlando Marques de Paiva 87, São Paulo, SP 05508-270, Brazil. E-mail: amaku@vps.fmvz.usp.br

The analysis of animal movement patterns may help identify farm premises with a potentially high risk of infectious disease introduction. Farm herd sizes and bovine movement data from 2007 in the state of Mato Grosso, Brazil, were analyzed. There are three different biomes in Mato Grosso: the Amazon, Cerrado, and Pantanal. The analysis of the animal trade between and within biomes would enable characterization of the connections between the biomes and the intensity of the internal trade within each biome. We conducted the following analyses: 1) the concentration of cattle on farm premises in the state and in each biome, 2) the number and relative frequency of cattle moved between biomes, and 3) the most frequent purposes for cattle movements. Twenty percent (20\%) of the farm premises had $81.15 \%$ of the herd population. Those premises may be important not only for the spread of infectious diseases, but also for the implementation of surveillance and control strategies. Most of the cattle movement was intrastate $(97.1 \%)$, and internal movements within each biome were predominant (88.6\%). A high percentage of movement from the Pantanal was to the Cerrado (48.6\%), the biome that received the most cattle for slaughter, fattening and reproduction $(62.4 \%, 56.8 \%$, and $49.1 \%$ of all movements for slaughter, fattening, and reproduction, respectively). The primary purposes for cattle trade were fattening $(43.5 \%)$, slaughter (31.5\%), and reproduction (22.7\%). Presumably, movements for slaughter has a low risk of disease spread. In contrast, movements for fattening and reproduction purposes $(66.2 \%$ of all movements) may contribute to an increased risk of the spread of infectious diseases.
\end{abstract}

INDEX TERMS: Cattle movement, herd size, biomes, Mato Grosso, infectious disease.

RESUMO.- [Trânsito de bovinos entre e dentro dos biomas no estado de Mato Grosso, Brasil.] A análise dos padrões de trânsito animal pode ajudar a identificar estabelecimentos sob um risco potencialmente maior de introdução de doença infecciosa. Foram analisadas a rede de trânsito de bovinos no estado do Mato Grosso, Brasil, e uma base de dados com

\footnotetext{
${ }^{1}$ Received on March 23, 2018.

Accepted for publication on May 10, 2018.

${ }^{2}$ Instituto de Defesa Agropecuária do Estado de Mato Grosso (Indea/MT), Av. Jorn. Arquimedes Pereira Lima 1000, Boa Esperança, Cuiabá, MT 78068-635, Brazil.

${ }^{3}$ Departamento de Medicina Veterinária Preventiva e Saúde Animal, Universidade de São Paulo (USP), Avenida Prof. Dr. Orlando Marques de Paiva 87, São Paulo, SP 05508-270, Brazil. *Corresponding author: amaku@vps.fmvz.usp.br

${ }^{4}$ Ministério da Agricultura Pecuária e Abastecimento, Brasília, DF 70632-100, Brazil.
}

tamanho de rebanho, ambas de 2007. Há três biomas diferentes em Mato Grosso: Amazônia, Cerrado e Pantanal. A análise do trânsito animal entre e dentro dos biomas nos permitiu caracterizar quão conectados são os biomas e quão intenso é o trânsito interno dentro de cada bioma. Conduzimos as seguintes análises: 1) se o rebanho bovino está concentrado em alguns estabelecimentos no estado todo e em cada bioma; 2) sobre o número absoluto e a frequência relativa de bovinos movimentados entre os biomas; e 3) quais são os propósitos mais frequentes para o trânsito animal. Encontramos que $20 \%$ dos estabelecimentos possuíam $81,15 \%$ do rebanho total do estado. Estes estabelecimentos podem ser importantes para o espalhamento de doenças infecciosas, mas também para a implementação de estratégias de vigilância e controle. A maior parte do trânsito foi dentro do estado (97,1\%), e o trânsito interno dentro de cada bioma foi predominante 
$(88,6 \%)$. Um percentual alto de movimentos do Pantanal $(48,6 \%)$ foi para o Cerrado, o bioma que recebeu mais bovinos para abate, engorda e reprodução $(62,4 \%, 56,8 \%$ e 49,1\% de todos os movimentos para abate, engorda e reprodução, respectivemente). Os principais propósitos para o comércio de bovinos foram engorda (43,5\%), abate $(31,5 \%)$ e reprodução $(22,7 \%)$. Movimentos para abate presumivelmente oferecem um baixo risco para espalhamento de doença. Em contraste, movimentos para engorda e reprodução $(66,2 \%$ de todos os movimentos) podem contribuir para o aumento do risco de espalhamento de doenças infecciosas.

TERMOS DE INDEXAÇÂO: Trânsito de bovinos, tamanho de rebanho, biomas, Mato Grosso, doença infecciosa, bovinos.

\section{INTRODUCTION}

The movement of animals between farm premises may contribute to the spread of infectious diseases. Hence, an understanding of the characteristics of the network of animal movements may help prevent or control the spread of diseases. In a scenario with no control measures in place, one could assume that the risk of disease spread between farm premises increases as the number of animals moved increases (Amaku et al. 2015). Thus, the analysis of animal movement may help identify farm premises with a potentially high risk of infectious disease introduction.

The state of Mato Grosso (MT) had the largest cattle herd (25.7 million cattle) in Brazil in 2007 (IBGE 2015b). There are three different biomes in the state (Fig.1): the Amazon (primarily rainforest), Cerrado (savannah), and Pantanal (floodplain). These biomes cover, respectively, $49 \%, 24 \%$, and $2 \%$ of the country (IBGE 2015a). Approximately $8 \%$ of the Cerrado and $40 \%$ of the Amazon are protected areas (Bustamante 2015). Thus, the intensity of livestock production and trade raises economic and environmental concerns. The analysis of the animal trade within and between biomes would enable the

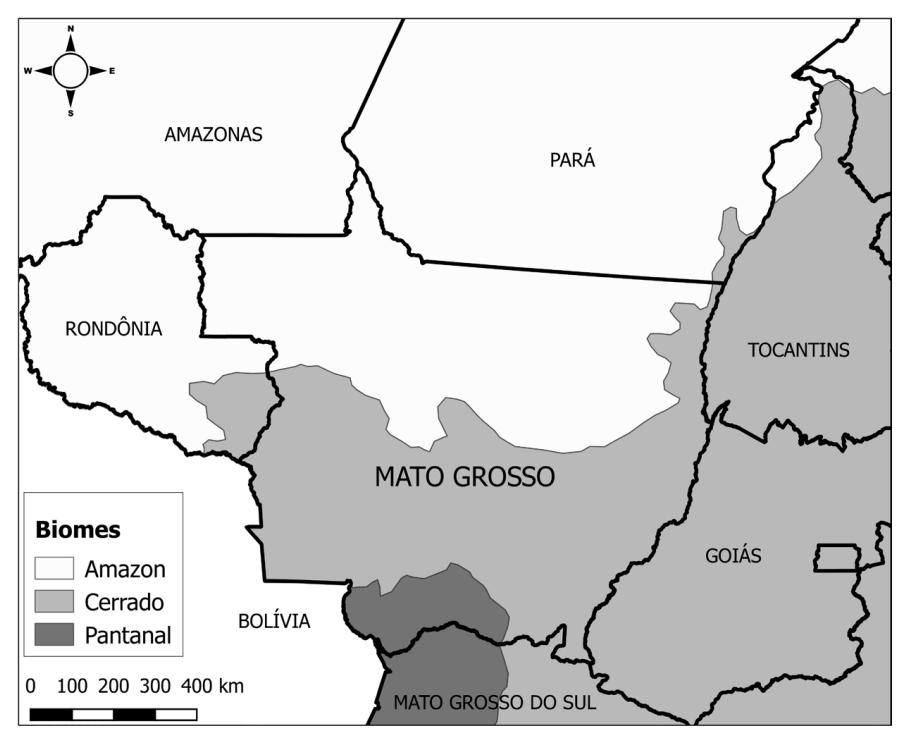

Fig.1. Map of the state of Mato Grosso, Brazil and the areas of the Amazon, Cerrado, and Pantanal biomes. characterization of the connections between biomes and the intensity of the internal trade within each biome.

Cipullo et al. (2016) reported an association between herd size and cattle trade in the state of Mato Grosso in 2007, and that larger size herds traded more animals than smaller herds. Herd size was also identified as a risk factor for bovine brucellosis in Mato Grosso (Negreiros et al. 2009). Thus, the analysis of the distribution of herd size, in the state and by biome, would contribute to the characterization of the herd distribution within the state.

Cipullo et al. (2016) analyzed the network for reproduction purposes and the network without abattoirs in Mato Grosso in 2007. They found a statistically significant difference between brucellosis, positive and negative farms, from a survey carried out in 2002-2003 (Negreiros et al. 2009) in the total number of bovines and batches of bovines moved, in the number of bovines and batches sold, and in the average herd size. These findings raise the question of whether the purposes for cattle movement are different in different biomes.

Our intention is to characterize the cattle trade between and within biomes in Mato Grosso. Using the 2007 data regarding network of bovine movements and premises herd sizes in Mato Grosso, we analyzed if the cattle herd is concentrated on some farm premises in the state and within each biome, the intensity of cattle movements between biomes in the state, and the most frequent purposes for cattle movements.

\section{MATERIALS AND METHODS}

Data on farm herd sizes on December 31, 2007 and on the cattle movement network in the state of Mato Grosso in 2007 were analyzed. Both databases (herd size and cattle movement network) were provided by the local veterinary agency (Instituto de Defesa Agropecuária do Estado de Mato Grosso, Indea/MT). Movements with origin and destination on the same premises were excluded from the analysis.

There were 112,924 premises registered with the 141 Indea/MT offices; 88,451 of those premises moved bovines in 2007. In addition, data on herd size were available for 100,216 premises, and biome identification (Amazon, Cerrado or Pantanal) was available for 67,945 farm premises.

The following analyses were performed: 1 ) if the cattle herd is concentrated on some farm premises, 2) the number and relative frequency of cattle moved between biomes, and 3) the most frequent purposes for cattle movement (reproduction, fattening, slaughter, exhibition, markets, or sports and work).

The median herd sizes of the three biomes were compared using the Kruskal-Wallis test. The analyses were performed in $\mathrm{R}$ (R Core Team 2017).

\section{RESULTS AND DISCUSSION}

Descriptive data on the area of the biomes, number of slaughterhouses, number of premises in the animal movement database, number of premises in each biome, and cattle moved from/to a given biome are shown in Table 1. Note that the biome Pantanal consistently (lower percentages) has the smallest area and the lowest number of slaughterhouses, premises, and cattle moved. In a comparison between the Cerrado and the Amazon, the Cerrado, which is a biome with an intense economic activity in Mato Grosso, has the smaller area and number of premises, but a higher number of slaughterhouses 
Table 1. Descriptive data regarding the biomes

\begin{tabular}{|c|c|c|c|}
\hline & Amazon & Cerrado & Pantanal \\
\hline \multirow[t]{2}{*}{ Area in square kilometers (\% of state area) (CMT 2018) } & 480,251 & 354,823 & 60,885 \\
\hline & $(53.6 \%)$ & $(39.6 \%)$ & $(6.8 \%)$ \\
\hline \multirow[t]{2}{*}{ Number of slaughterhouses in the animal movement database } & 19 & 43 & 5 \\
\hline & $(28.3 \%)$ & $(64.2 \%)$ & $(7.5 \%)$ \\
\hline \multirow[t]{2}{*}{ Number of premises in Mato Grosso analyzed in the animal movement database } & 42,914 & 39,661 & 5,108 \\
\hline & $(48.9 \%)$ & $(45.2 \%)$ & $(5.8 \%)$ \\
\hline \multirow[t]{2}{*}{ Cattle moved from the biome } & $6,475,775$ & $7,931,595$ & $1,098,725$ \\
\hline & $(41.8 \%)$ & $(51.1 \%)$ & $(7.1 \%)$ \\
\hline \multirow[t]{2}{*}{ Cattle moved to the biome } & $5,854,965$ & $8,880,314$ & 770,816 \\
\hline & $(37.7 \%)$ & $(57.3 \%)$ & $(5.0 \%)$ \\
\hline
\end{tabular}

and cattle moved. On the other hand, the Amazon has the larger area and number of premises, but a lower number of slaughterhouses and animals moved. The cover extent of Amazon forest (Morton et al. 2011) could partially explain the lower volume of animal trade in comparison to the Cerrado.

Other cattle movement studies were performed in the Brazilian states of Pernambuco (Silva Júnior et al. 2017), Mato Grosso and Mato Grosso do Sul (Capanema et al. 2012), and Paraná and Santa Catarina (Felipe et al. 2013). Capanema et al. (2012) and Felipe et al. (2013) analyzed the cattle movement for slaughter and identified the slaughter poles. As mentioned by Silva Júnior et al. (2017), in the cattle movement of Mato Grosso, Negreiros (2010) observed that slaughterhouses were important hubs of the cattle trade network, followed by markets and big farms. Beef production for national and international consumer markets is an important economic activity in Mato Grosso (Silva Júnior et al. 2017). In contrast, in Pernambuco the majority of cattle production is in small scale and livestock markets were important hubs (Silva Júnior et al. 2017).

The distribution of herd size by biome is shown in Figure 2 . The Kruskal-Wallis test revealed a significant difference among the median herd sizes of the three biomes $(p<0.001)$. The median herd sizes and the corresponding interquartile ranges (IQR) for the Amazon, Cerrado, and Pantanal were 98 (IQR: 39-269), 110.5 (IQR: 43-333), and 148 cattle (IQR: 50-494.2), respectively (Table 2).

The analyzed database included 26.9 million cattle. An analysis of herd size revealed that $20 \%$ of the farm premises had between 1 and 19 cattle ( $0.75 \%$ of the state herd); $20 \%$ of the farm premises had between 19 and 42 cattle $(2.20 \%$ of the state herd); $20 \%$ of the farm premises had between 42 and 90 cattle ( $4.70 \%$ of the state herd); $20 \%$ of the farm premises had between 90 and 248 cattle $(11.20 \%$ of the state herd); and $20 \%$ of the farm premises had between 248 and 136,005 cattle (81.15\% of the state herd).

Figure 3 shows the percentage of the total herd size as a function of the percentage of the largest herds in the three biomes and in the state. The curves for the three biomes are similar, and the $20 / 80$ rule applies approximately to all three biomes: the largest $20 \%$ of the herds included approximately $77 \%$ of the total population. Statewide, the largest $20 \%$ of the herds included $81.15 \%$ of the total population, as mentioned above. Biome identification was available for only $68 \%$ of
Table 2. Descriptive statistics of herd size by biome, showing the minimum, the first quartile (Q1), the median, the mean, the third quartile (Q3), and the maximum value

\begin{tabular}{cccc}
\hline Parameter & Amazon & Cerrado & Pantanal \\
\hline Minimum & 1 & 1 & 1 \\
Q1 & 39 & 43 & 50 \\
Median & 98 & 110.5 & 148 \\
Mean & 350.1 & 415.6 & 545.5 \\
Q3 & 269 & 333 & 494.2 \\
Maximum & 94,664 & 47,839 & 35,954
\end{tabular}

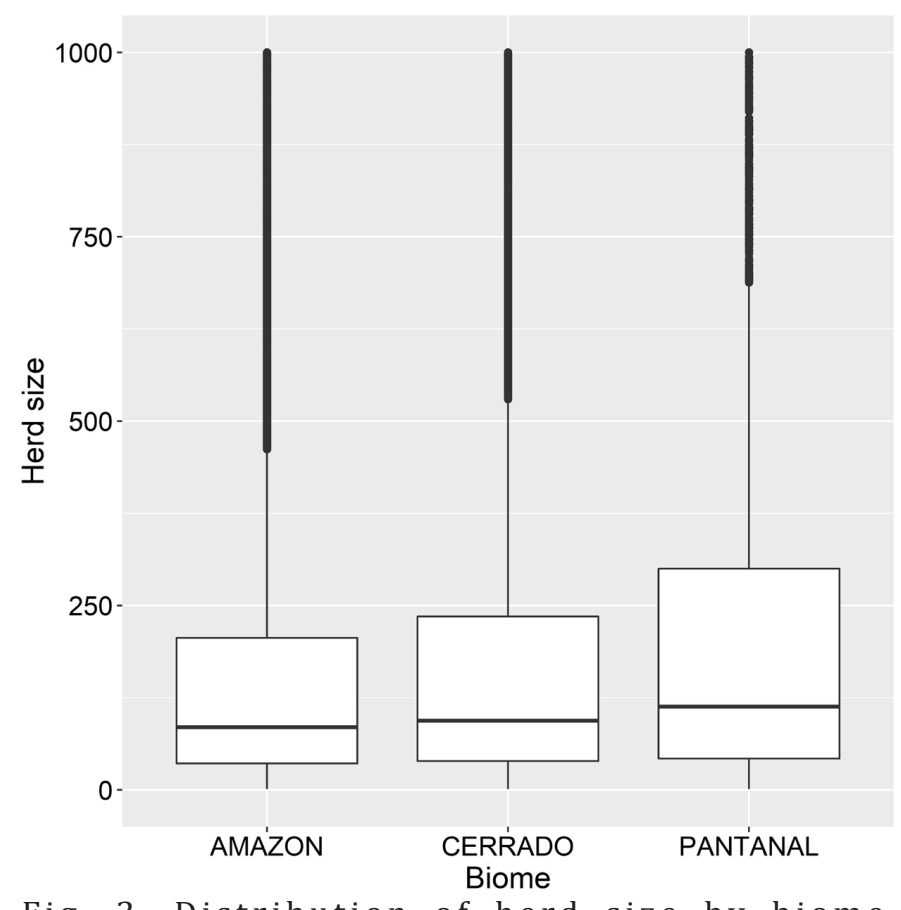

Fig. 2. Distribution of herd size by biome.

all herds in the dataset, which may explain the discrepancy between the ratio observed for the state and for each biome.

This finding approximately obeys the 20/80 Pareto Principle and indicates that roughly $80 \%$ of the state herd is 
concentrated on $20 \%$ of the farm premises. Cipullo et al. (2016) analyzed the same database and observed that herd size and animal trade were positively associated, and also that farms positive for bovine brucellosis in the 2003 survey were trading and selling more than the negative farms in 2007, which presumably increased the risk of disease dissemination. Hence, the primary cattle traders are potential spreaders of infectious diseases through the animal trade network and deserve special attention from the veterinary surveillance system.

Table 3 shows the number and percentage of cattle moved intrastate and interstate for different purposes. Most cattle movement was intrastate (97.1\%). Of the 15,965,825 bovines moved within the state, 6,944,103 (43.5\%), 5,031,387 (31.5\%), and $3,623,514(22.7 \%)$ were moved for fattening, slaughter, and reproduction, respectively. In the state of Pernambuco, most cattle movement (91.3\%) was also intrastate (Silva Júnior et al. 2017).

Analysis of bovine movement by biome revealed that most bovines were moved within the same biome (Fig.4). The Cerrado received the most bovines for slaughter, fattening, and reproduction (Table 4); it was the destination of $62.4 \%$, $56.8 \%$, and $49.1 \%$ of all movements for slaughter, fattening, and reproduction, respectively.

Analysis of movements between biomes (Table 4 and Fig.4) revealed the percentage of movements from the Pantanal (48.6\%) or the Amazon (12.6\%) to the Cerrado. In absolute figures, the number of bovines $(398,430)$ moved from the Cerrado to the Pantanal or the Amazon was less than the number $(1,347,149)$ moved from the other two biomes to the Cerrado. Of the 15,506,095 bovines moved within the state, 1,762,305 (11.4\%) were moved between biomes. Thus, internal movement within each biome was predominant (Fig.4). When cattle purchases were analyzed, including movements within each biome, the Pantanal had the lowest rate of cattle purchased (5.0\%). As presented in Figure 1, the Pantanal is also the smallest of the three biomes. Although the

Table 3. Cattle moved for different purposes in the state of Mato Grosso

\begin{tabular}{ccccc}
\hline \multirow{2}{*}{ Purpose } & Intrastate & & Interstate & \multirow{2}{*}{ Total } \\
\cline { 2 - 3 } \cline { 5 - 5 } Slaughter & (\% of total) & & (\% of total) & \\
\cline { 5 - 5 } Fattening & $4,776,943$ & & 254,444 & $5,031,387$ \\
& $(29.9 \%)$ & & $(1.6 \%)$ & $(31.5 \%)$ \\
Reproduction & $6,762,209$ & & 181,894 & $6,944,103$ \\
& $(42.4 \%)$ & & $(1.1 \%)$ & $(43.5 \%)$ \\
Exhibition & $(22.600,964$ & & 22,550 & $3,623,514$ \\
& 16,838 & & $(0.14 \%)$ & $(22.7 \%)$ \\
Market & $(0.11 \%)$ & & $(0.0027 \%)$ & $(0.11 \%)$ \\
& 342,406 & & 398 & 342,804 \\
Sports/Work & $(2.1 \%)$ & & $(0.0025 \%)$ & $(2.1 \%)$ \\
& 6,735 & & 9 & 6,744 \\
TOTAL & $(0.04 \%)$ & & $(0.000056 \%)$ & $(0.04 \%)$ \\
& $15,506,095$ & & 459,730 & $15,965,825$ \\
& $(97.1 \%)$ & & $(2.9 \%)$ &
\end{tabular}

Pantanal had the least intense trade, an important extension of the Brazilian international frontier is in the Pantanal area.

Transport within each biome was predominant $(88.6 \%$ of all movements). This finding is partially related to the community structure observed in cattle movement among the counties in Mato Grosso in 2007 (Grisi-Filho et al. 2013), and

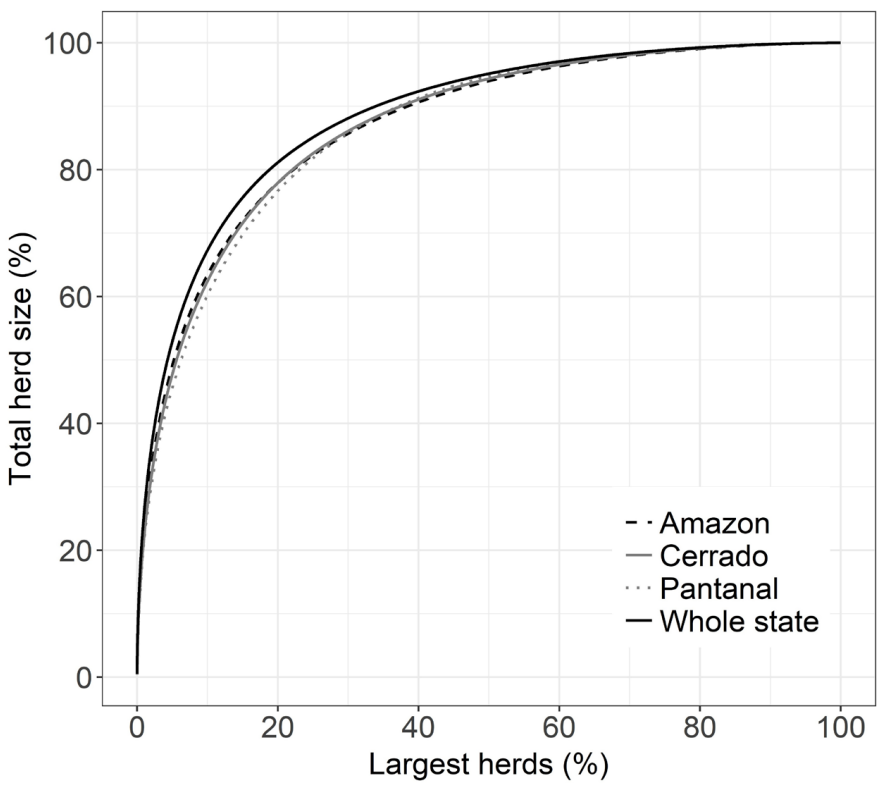

Fig. 3. Percentage of total herd size as a function of the percentage of the largest herds in each biome and in Mato Grosso.

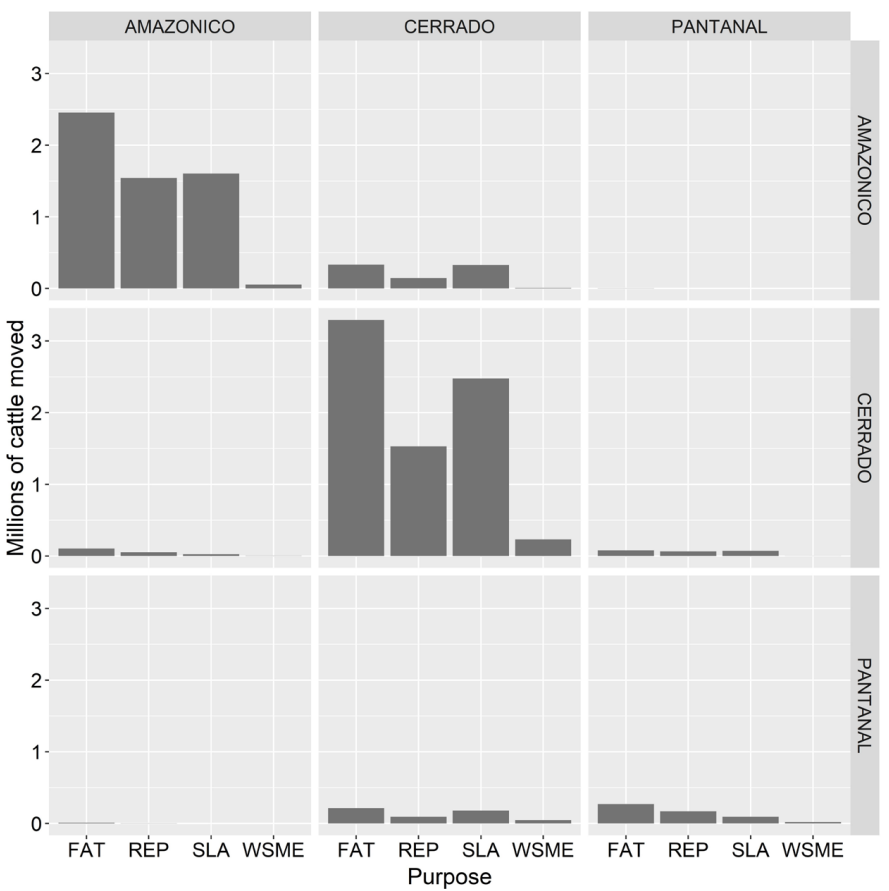

Fig. 4. Number of cattle moved from a point of origin (row) to a destination (column) biome by purpose. FAT = fattening, $\mathrm{REP}=$ reproduction, $\mathrm{SLA}=$ slaughter, $\mathrm{WSME}=$ work, sport, market, or exhibition. 
Table 4. Cattle moved for slaughter, fattening, and reproduction by biome

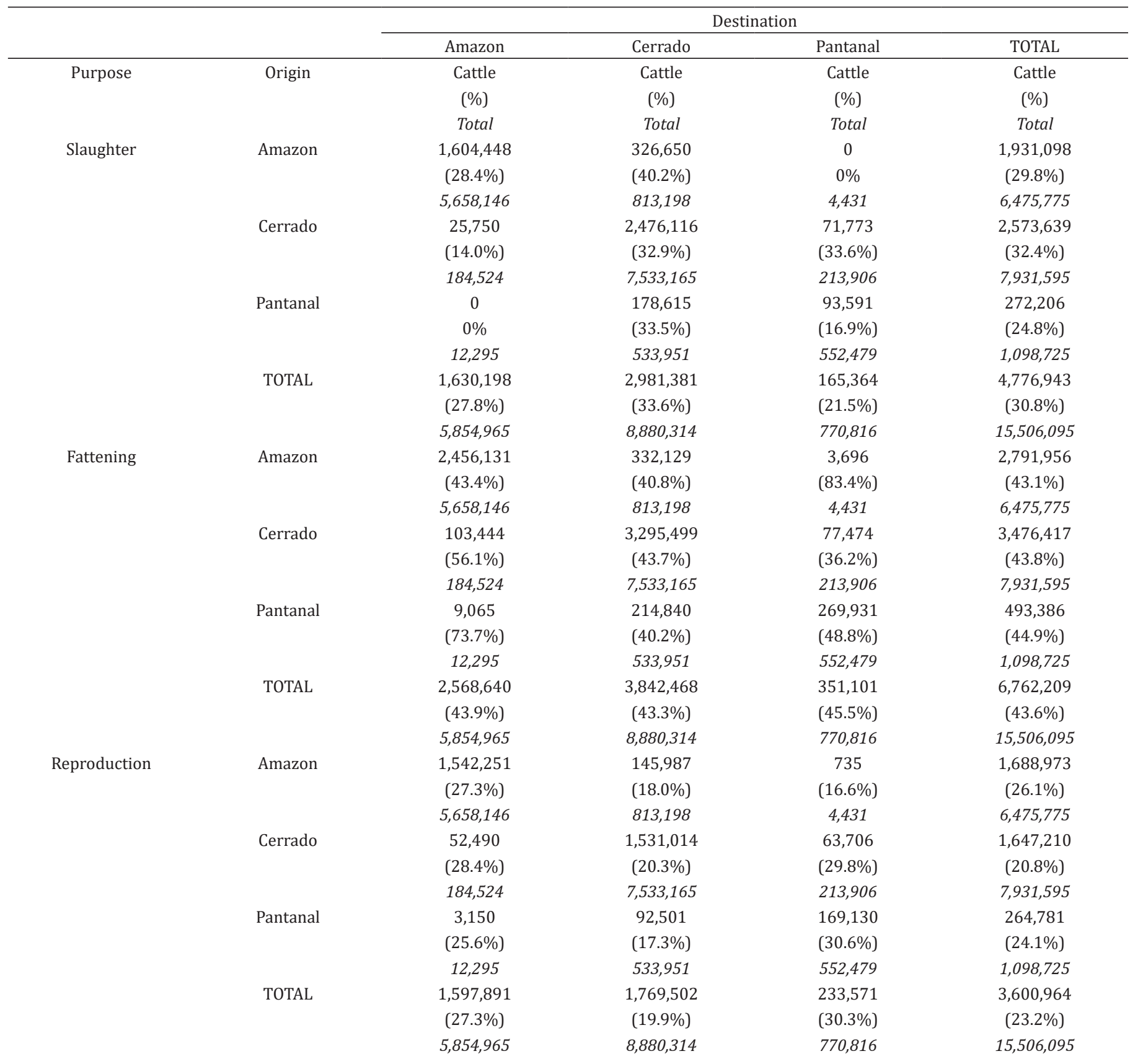

potentially related to a preference for short- or medium-distance (a median less than 100 kilometers) movements (Negreiros 2010). When we consider only intrastate movements, the median geodesic spatial distance (in kilometers) for the batches moved from the biomes Amazon, Cerrado, and Pantanal were 73 (IQR: 35-159), 77 (IQR: 36-153), and 97 (IQR: 59-143), respectively. The interquartile ranges were similar for the Amazon and the Cerrado, but the median distance for the Pantanal was longer. However, the distance distribution for all biomes is compatible with a short- or medium-distance movement pattern, suggesting that spatial closeness, potentially related to an underlying network of cattle trade, is a determinant factor for animal movement.
The percentages of animals moved for slaughter within the Amazon, Cerrado, and Pantanal biomes were $27.8 \%$, $33.6 \%$, and $21.5 \%$, respectively, with regard to all movements to that biome (Table 4). The percentages of animals moved for fattening were $43.9 \%, 43.3 \%$, and $45.5 \%$, respectively. The percentages of animals moved for reproduction were $27.3 \%, 19.9 \%$, and $30.3 \%$, respectively. Thus, in all biomes, movements for fattening prevailed over movements for slaughter or reproduction. Interestingly, in the Pantanal, we observed a higher percentage of animals moved for reproduction (30.3\%) than for slaughter (21.5\%). Historically, the Pantanal has been considered a breeding area (Santos et al. 2002). There was a low number of slaughterhouses in the Pantanal (Table 1) and 
the slaughtering of most cattle from the Pantanal occurred in the Cerrado (Table 4). The percentage of animals moved for slaughter from the Amazon was similar to the percentage moved for reproduction.

Cattle movement for slaughter has a low risk of disease dissemination. However, movement for fattening or reproduction may contribute to the spread of certain diseases, such as bovine brucellosis, which had a herd prevalence of $41.2 \%$ in the state according to a survey performed in 2002 and 2003 (Negreiros et al. 2009). The herd prevalence was reduced to $24.0 \%$ in 2014 (Bardall et al. 2016).

Although the Amazon was the biome with the largest number of premises in Mato Grosso in the analyzed animal movement network (Table 1), probably related to its large area, it was not the biome with the most intense cattle trade pattern (Fig.4). Our findings suggest that, regarding cattle trade, all biomes were anthropized. The economic activity in Mato Grosso is intense in the Cerrado area. Amongst the 11 Mato Grosso counties with more than 50,000 inhabitants (Wikipedia 2018), 8 are located in the Cerrado, 2 in the Amazon and 1 in the Pantanal biome. Cerrado was the biome with the most intense cattle trade pattern (Fig.4), what presumably explains the fact that the largest number of slaughterhouses in Mato Grosso was in the Cerrado. Capanema et al. (2012) found four counties that were important poles in the cattle movement for slaughter in Mato Grosso, three located in the Cerrado and one in the Amazon. Although the median herd size in the Pantanal was the largest (Table 2), the least intense cattle trade pattern was observed there, which could be related to the smallest area, the lowest number of farm premises and slaughterhouses, and also to the environmental constraints since it is a floodplain.

\section{CONCLUSIONS}

Twenty percent (20\%) of the farm premises had $81.15 \%$ of the Mato Grosso state herd in 2007. Those farms may be important for the spread of infectious diseases and, conversely, for the implementation of surveillance and control strategies.

Most cattle movement was intrastate (97.1\%); within the state, internal movements within each biome were predominant (88.6\%).

The primary purposes for the cattle trade were fattening $(43.5 \%)$, slaughter $(31.5 \%)$, and reproduction $(22.7 \%)$. Movement for slaughter has a low risk of disease spread. However, movement for fattening or reproduction (66.2\%) may contribute to an increased risk of the spread of certain infectious diseases, such as bovine brucellosis.

Acknowledgments.- The authors are grateful to the Indea/MT for providing the databases. The authors acknowledge financial support from CNPq and Capes.

\section{REFERENCES}

Amaku M., Grisi-Filho J.H.H., Negreiros R.L., Dias R.A., Ferreira F., Ferreira Neto J.S., Cipullo R.I., Marques F.S. \& Ossada R. 2015. Infectious disease surveillance in animal movement networks: an approach based on the friendship paradox. Prev. Vet. Med. 121(3/4):306-313. <http://dx.doi. org/10.1016/j.prevetmed.2015.08.002><PMid:26277202>

Bardall J.E.I., Quixabeira-Santos J.C., Lopes I.F., Ferreira Neto J.S., Ferreira F., Amaku M., Dias R.A., Telles E.O., Grisi-Filho J.H.H., Heinemann M.B., Gonçalves V.S.P. \& Aguiar D.M. 2016. Effect of vaccination in lowering the prevalence of bovine brucellosis in the state of Mato Grosso, Brazil. Semina, Ciênc. Agrárias 37(5 Suppl. 2):3479-3492.

Bustamante M. 2015. Política de clima negligencia o Cerrado: mais uma vez. Observatório do Clima, November 24, 2015. Available at <http://www. observatoriodoclima.eco.br/politica-de-clima-negligencia-o-cerrado-maisuma-vez/> Accessed on Dec. 3, 2015.

Capanema R.O., Haddad J.P.A. \& Felipe P.L.S. 2012. Trânsito de bovinos nos estados do Mato Grosso e Mato Grosso do Sul, Brasil. Arq. Bras. Med. Vet. Zootec. 64(2):253-262. <http://dx.doi.org/10.1590/S0102$09352012000200002>$

Cipullo R.I., Dias R.A., Ferreira F., Ferreira Neto J.S., Gonçalves V.S.P., Marques F.S., Negreiros R.L., Ossada R. \& Amaku M. 2016. Cattle movement network, herd size, and bovine brucellosis in the State of Mato Grosso, Brazil. Semina, Ciênc. Agrárias 37(5 Suppl. 2):3777-3792.

CMT 2018. Biomas. Coisas de Mato Grosso, Mato Grosso. Available at <http:// www.coisasdematogrosso.com.br/mato-grosso/biomas/> Accessed on Mar. 2, 2018.

Felipe P.L.S., Nicolino R.R., Capanema R.O. \& Haddad J.P.A. 2013. Caracterização do trânsito bovino no estado do Paraná e Santa Catarina, Brasil, 2008. Arq. Bras. Med. Vet. Zootec. 65(3):659-668. <http://dx.doi.org/10.1590/ S0102-09352013000300007>

Grisi-Filho J.H.H., Amaku M., Ferreira F., Dias R.A., Ferreira Neto J.S., Negreiros R.L. \& Ossada R. 2013. Detecting livestock production zones. Prev. Vet. Med. 110(3-4):304-311.<http://dx.doi.org/10.1016/j.prevetmed.2012.12.013> $<$ PMid:23434375>

IBGE 2015a. Mapas de biomas e de vegetação. Instituto Brasileiro de Geografia e Estatística. Available at <http://www.ibge.gov.br/home/presidencia/ noticias/21052004biomashtml.shtm> Accessed on Dec. 3, 2015.

IBGE 2015b. Pesquisa pecuária municipal. Instituto Brasileiro de Geografia e Estatística. Available at <http://www.sidra.ibge.gov.br/bda/tabela/protabl. asp?c=73\&z=p\&o=29\&i=P $>$ Accessed on Nov. 24, 2015.

Morton D.C., Sales M.H., Souza Junior C.M. \& Griscom B. 2011. Historic emissions from deforestation and forest degradation in Mato Grosso, Brazil: 1) source data uncertainties. Carbon Balance Manag. 6(1):18. <http:// dx.doi.org/10.1186/1750-0680-6-18><PMid:22208947>

Negreiros R.L. 2010. Caracterização e análise da rede de movimento de bovinos no Estado de Mato Grosso. Tese de Doutorado em Epidemiologia Experimental Aplicada às Zoonoses, Faculdade de Medicina Veterinária e Zootecnia, Universidade de São Paulo, São Paulo. 121p.

Negreiros R.L., Dias R.A., Ferreira F., Ferreira Neto J.S., Gonçalves V.S.P., Silva M.C.P., Figueiredo V.C.F., Lôbo J.R., Freitas J. \& Amaku M. 2009. Situação epidemiológica da brucelose bovina no Estado de Mato Grosso. Arq. Bras. Med. Vet. Zootec. 61(Suppl. 1):56-65. <http://dx.doi.org/10.1590/S010209352009000700008>

R Core Team 2017. R: a language and environment for statistical computing. Vienna, Austria, Available at <http://www.r-project.org > Accessed on Jul. 7, 2017.

Santos S.A., Pellegrin A.O., Moraes A.S., Barros A.T.M., Comastri Filho J.A., Sereno J.R.B., Silva R.A.M.S. \& Abreu U.G.P. 2002. Sistema de produção de gado de corte no Pantanal. Embrapa Pantanal, Corumbá. 82p.

Silva Júnior J.L., Almeida E.C., Corrêa F.N., Lima P.R.B., Ossada R., Marques F.S., Dias R.A., Ferreira F., Ferreira Neto J.S., Grisi-Filho J.H.H., Amaku M., Manso Filho H.C. \& Silva J.C.R. 2017. Livestock markets play an important role in the cattle movement network in Pernambuco, Brazil. Braz. J. Vet. Res. Anim. Sci. 54(3):225-237. <http://dx.doi.org/10.11606/issn.16784456.bjvras.2017.124303>

Wikipedia 2018. Lista de Municípios de Mato Grosso por População. Available at <https://pt.wikipedia.org/wiki/Lista_de_munic\%C3\%ADpios_de_ Mato_Grosso_por_popula\%C3\%A7\%C3\%A3o > Accessed on Mar. 8, 2018. 